\title{
Mesozoic mantle-crust interaction in the Eastern Tianshan, southern of the Central Asian Orogenic Belt
}

\author{
Ru-Xiong LeI ${ }^{1}$, Chang-Zhi Wu², Yong-Gang Feng ${ }^{1}$ \\ ${ }^{1}$ Key Laboratory of Western China's Mineral Resources and \\ Geological Engineering, Ministry of Education, College \\ of Earth Sciences and Resource, Chang'an University, \\ Xi'an 710054, China, ruxionglei@chd.edu.cn. \\ ${ }^{2}$ State Key Laboratory for Mineral Deposits Research, \\ School of Earth Sciences and Engineering, Nanjing \\ University, Nanjing 210046, China.
}

The Eastern Tianshan orogenic belt, located in the southern part of the CAOB, experienced a complex and entire accretionary geodynamic evolution through Paleozoic oceanic plate subduction and progressive accretion, to ocean closure and continental collision and post collisional extension, as well as to Mesozoic intracontinental reactivation. Mesozoic (Triassic) magmatism has been increasingly identified in the Eastern Tianshan and played a crucial role in the late-stage evolution of the CAOB. New field and petrological observations, zircon LA-ICP-MS U-Pb ages and Hf isotopic compositions, and whole-rock geochemical data for the Triassic mafic dikes, microgranular enclaves (MEs) and host granitoids are used to investigate their origin and the Triassic tectonic regime of the Eastern Tianshan. Zircon U$\mathrm{Pb}$ ages indicates that mafic dikes, the granitoids and MEs have similar early Triassic ages (ca. $245 \mathrm{Ma}-250 \mathrm{Ma}$ ). The mafic dikes with high $\mathrm{Mg} \#$ crosscut the granitoids. The MEs occur sub-rounded to ellipsoidal in shape commonly in the host granitoids. Acicular apatite, cellular plagioclase and quartz xenocryst occur in the MEs, and the MEs have high $\mathrm{Mg \#}$ with positive $\varepsilon \mathrm{Hf}(\mathrm{t})$ values and younger model ages, suggesting a mantle-derived source. The host Tianhu granitoids belong to I-type granite and have high $\varepsilon \mathrm{Hf}(\mathrm{t})$ values and younger $\mathrm{Hf}$ model ages. All these characteristics indicate that the Tianhu granitoids and MEs were likely formed through mixing between mafic and felsic magmas with mantle-crust interaction. The mafic magma was derived from the partial melting of a depleted mantle source, whereas the felsic magma was generated by partial melting of the lower crust. An upwelling of the asthenosphere leads to initial melting of the lithospheric mantle to form mafic magmas. Ascending of the mafic magmas triggered melting of juvenile deep crustal material to generate felsic magmas. Combined with the avialble geological evidence, our new results suggest that Triassic mantle-crust interaction occurred in the Eastern Tianshan. 